
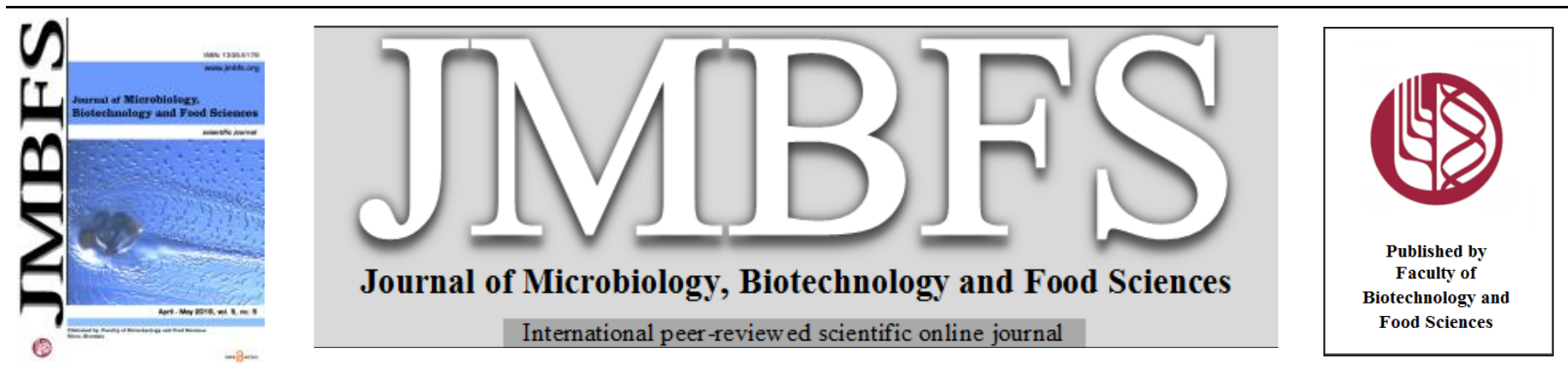

\title{
ANTIMICROBIAL ACTIVITY OF SOME ESSENTIAL OILS ALONE AND IN COMBINATION WITH AMIKACIN AGAINST ACINETOBACTER SP
}

\author{
Mohaddese Mahboubi ${ }^{1}$, Mohammad Mehdi Feizabadi ${ }^{2}$ \\ Address(es): Dr. Mohaddese Mahboubi, \\ ${ }^{1}$ Microbiology Department, Medicinal Plant Research Center of Barij, Kashan, Iran. \\ ${ }^{2}$ Department of Microbiology, Faculty of Medical Sciences, University of Tehran, Iran.
}

*Corresponding author: mahboubi@barijessence.com, mahboubi1357@yahoo.com

doi: 10.15414/jmbfs.2016.5.5.412-415

\section{ARTICLE INFO}

Received 6. 5. 2014

Revised 2. 12. 2015

Accepted 12.1.2016

Published 1. 4. 2016

Regular article

OPEN $\partial_{\text {ACCESS }}$

\begin{abstract}
Acinetobacter sp. as gram negative bacilli is one of the most problematic bacteria in hospital environments. The emergence of multidrug resistant isolates of Acinetobacter sp. encourages the scientists to find the new antimicrobial agent with less side effects. The aim of this study was to evaluate the antibacterial activity of Cymbopogon olivieri, Heracleum persicum, Juniperus comminus, Azillia eryngioides, Dacus carrota, Ferula gummosa, Acorus calamus, Mentha pulegium, Achillea biebersteinii, and Chaerophyllum macropodum essential oils against clinical trials of Acinetobacter sp. by disc diffusion and micro broth dilution assays. The synergistic effect of these essential oils and amikacin (AMI) were determined. The higher inhibition zone diameters were for $2 \mu 1$ of $C$. macropodum $(15.3 \pm 0.48 \mathrm{~mm})$. The lower MIC and MBC values were for C. olivieri $(1.4$ and $1.9 \mu \mathrm{l} / \mathrm{ml})$ and J. comminus $(1.9$ and 2.6 $\mu 1 / \mathrm{ml})$, followed by C. macropodum (2.01 and $3.2 \mu \mathrm{l} / \mathrm{ml})$, D. carrota $(2.1$ and $3.8 \mu 1 / \mathrm{ml})$, A. eryngioides $(2.3$ and $3.1 \mu 1 / \mathrm{ml})$ essential oils and $F$. gummosa $(2.4$ and $4 \mu \mathrm{l} / \mathrm{ml})$. AMI showed synergistic effect with all of the essential oils. D. carrota and A. eryngioides showed the best synergistic effect with AMI, followed by C. macropodum, A. biebersteinii, J. comminus and F. gummosa essential oils.
\end{abstract}

Keywords: Acinetobacter sp., essential oil, synergistic effect, amikacin

\section{INTRODUCTION}

Acinetobacter sp. isolates are problematic pathogens in intensive-care units and other hospital units in recent years. They are the causes of health care associated pneumonia, surgical site infections, bloodstream infections, urinary tract infections (Tolbat et al., 2006). Acinetobacter sp. isolates with multi drug resistance (MDR) are markedly increasing and treatment of Acinetobacter sp. infections have been limited to few broad spectrum antibiotics, including carbapenems, amikacin, doxycycline, minocycline, and ampicillin/sulbactam (Van Looveren and Guossens, 2004). As resistance to antibiotics has emerged, the mortality rates in Acinetobacter sp. infected patients have increased. Therefore, the popularity of natural essential oils as alternative treatment has increased (Sienkiewicz et al., 2011; Mikaili et al., 2011; Candan et al., 2003; Damjanovic- Vratnica et al., 2011).

In this research, we isolated 35 clinical isolates of Acinetobacter sp. and determined the sensitivity of these isolates to different antibiotics; then we evaluate the anti Acinetobacter sp. activity of ten essential oils alone against clinical isolates of Acinetobacter sp. The combination of ten different essential oils with amikacin (AMI) was evaluated against one AMI resistant isolates by measuring the FIC and FIC indexes.

\section{MATERIAL AND METHODS}

\section{Essential oils and their analysis}

10 different essential oils including Cymbopogon olivieri, Heracleum persicum, Juniperus comminus, Azillia eryngioides, Dacus carrota, Ferula gummosa, Acorus calamus, Mentha pulegium, Achillea biebersteinii and Chaerophyllum macropodum were prepared from Barij Essence Pharmaceutical Company. The essential oils were analyzed using GC-FID and GC-MS. The GC-FID and GCMS apparatus were conducted on an HP 6890 GC system coupled with 5973 network mass selective detectors with a capillary column of HP-5MS $(30 \mathrm{~m} \times$ $0.25 \mathrm{~mm}$, film thickness $0.25 \mu \mathrm{m}$ ). The oven temperature program was initiated at $60{ }^{\circ} \mathrm{C}$, held for $1 \mathrm{~min}$, then raised up to $245^{\circ} \mathrm{C}$ at a rate of $3{ }^{\circ} \mathrm{C} / \mathrm{min}$ held for 10 min. Helium was used as the carrier gas at a flow rate $1.5 \mathrm{ml} / \mathrm{min}$. The detector and injector temperatures were 250 and $230{ }^{\circ} \mathrm{C}$, respectively. The compounds of the essential oil were identified by comparison of their retention indices (RI), mass spectral fragmentation with those in the stored Wiley $7 \mathrm{n} .1$ mass computer library (Adams, 2001).

\section{Antibiotics}

The antibiotic discs that were used in this study including ciprofloxacine (CIPR 5 $\mu \mathrm{g}$ ), cefepime (FEP $30 \mu \mathrm{g}$ ), ceftazidime (CAZ $30 \mu \mathrm{g}$ ), levofloxacin (LEVOF 5 $\mu \mathrm{g}$ ), amikacin (AMI $30 \mu \mathrm{g}$ ), amoxicillin (AMOXY $30 \mu \mathrm{g}$ ), Imipenem (IMI 10 $\mu \mathrm{g}$ ), tobramycin (TOB $10 \mu \mathrm{g}$ ), cefotaxim (CTX $30 \mu \mathrm{g}$ ), norfloxacin (NOR 10 $\mu \mathrm{g}$ ), ampicillin+sulbactam (SAM $20 \mu \mathrm{g}(10+10)$ ), meropenem (MRP $10 \mu \mathrm{g}$ ), gentamicin (GEN $10 \mu \mathrm{g}$ ), piperacillin+tazobactum (PI 100+ IZ $10 \mu \mathrm{g}$ ), amoxicillin+clavulonate (AMC $30 \mu \mathrm{g} ;(20+10))$ were purchased from Rosco (Diagnostica A/S, Taastrupgaardsvej 30 DK-2630 Taastrup).

\section{Acinetobacter isolates and antimicrobial susceptibility testing}

A total of 35 clinical isolates cultured from different samples of wounds, trachea, blood, CSF, catheter and other samples of patients at hospitals from Tehran were the subject of this investigation. Antimicrobial susceptibility testing was evaluated using disc diffusion (NCCLS, 2012) and micro broth (CLSI, 2009) dilution assays. This inoculate of microorganism was adjusted to 0.5 McFarland $\left(1 \times 10^{7}-1 \times 10^{8} \mathrm{CFU} / \mathrm{ml}\right)$ and using a sterile cotton swab, the microbial suspensions were cultured on appropriate media. Subsequently, sterile blank discs $(6 \mathrm{~mm}$ in diameter) were saturated with $0.5,1$ and $2 \mu 1$ of essential oil and were put on the cultured media. The plates were incubated at $37^{\circ} \mathrm{C}$ for $24 \mathrm{~h}$. The inhibition zones (IZ) diameters were measured in millimeters $(\mathrm{mm})$ and average of IZ was recorded as means $\pm \mathrm{SD}$ (Standard Deviation).

The minimal inhibitory concentration (MIC) and minimal Bactericidal Concentration (MBC) values of essential oils were determined by micro broth dilution assay. The essential oil was twofold serially diluted $(8-0.0125 \mu \mathrm{l} / \mathrm{ml}$ of essential oil). Cation adjusted Muller Hinton broth was used as broth media. After shaking, $100 \mu 1$ of essential oil was added to each well. The above microbial suspensions were diluted to $1 \times 10^{6}$ and then $100 \mu 1$ were added to each well and incubated at $35 \pm 2{ }^{\circ} \mathrm{C}$. MIC was defined as the lowest concentration of essential oil that inhibits bacteria after $24 \mathrm{~h}$. MBC value was the first well that 
showed no growth on suitable media. All experiments were done in triplicates.Statistical data analysis was performed by SPSS software (version 17 Chicago, Illinois, USA). Statistical analysis (ANOVA) was applied to determine the differences $(\mathrm{P}<0.05)$. Significant differences between the essential oils and microorganisms were determined by Tukey test.

\section{Checkerboard titer test}

AMI were purchased from Sigma-Aldrich Co. LLC. and dissolved in water. The dilutions were prepared in water in concentration $64-0.0125 \mu \mathrm{g} / \mathrm{ml}$ and the antimicrobial susceptibility testing was performed as CLSI procedure (CLSI, 2009)

Eight serial twofold dilutions of essential oils and AMI were used. Fifty $\mu 1$ of each dilution of essential oil was added to the wells of 96-well plates in vertica orientation and $10 \mu \mathrm{l}$ of AMI dilution was added in horizontal orientation. $50 \mu 1$ of AMI resistant Acinetobacter sp $\left(10^{6} \mathrm{CFU} /\right.$ well $)$ was added to each well and incubated for $24 \mathrm{~h}$. Fractional inhibitory concentrations (FICs) were calculated as the MIC of the combination of essential oil and AMI divided by the MIC of essential oil or AMI alone. The FIC index (FICI) was interpreted as a synergistic effect when it was $\leq 0.5$, as additive or indifferent when it was $>0.5-2$ and as antagonistic when it was $>2.0$ (Rosato et al., 2007).

Table 1 Antibiotic resistant profile of clinical isolates of Acinetobacter $\mathrm{sp}$.

\begin{tabular}{lc}
\hline Antibiotics & Resistance $(\%)$ \\
\hline CIPR & $(12 / 35) \mathbf{6 5 . 7}$ \\
FEP & $(14 / 35) \mathbf{6 0}$ \\
CAZ & $(9 / 35) \mathbf{7 4 . 2}$ \\
LEVOF & $(18 / 35) \mathbf{4 8 . 6}$ \\
AMI & $(20 / 35) \mathbf{4 2 . 9}$ \\
AMOXY & $(1 / 35) \mathbf{9 7 . 1}$ \\
IMI & $(12 / 35) \mathbf{6 5 . 7}$ \\
TOB & $(26 / 35) \mathbf{2 5 . 7}$ \\
CTX & $(3 / 35) \mathbf{9 1 . 4}$ \\
NORFX & $(9 / 35) \mathbf{7 4 . 3}$ \\
SAM & $(14 / 35) \mathbf{6 0}$ \\
MRP & $(12 / 35) \mathbf{7 4 . 3}$ \\
GEN & $(10 / 35) \mathbf{7 1 . 4}$ \\
PI+IZ & $(13 / 35) \mathbf{6 2 . 8}$ \\
AMC & $(9 / 35) \mathbf{7 4 . 2}$ \\
\hline
\end{tabular}

$\mathrm{CIPR}=$ ciprofloxacine; $\mathrm{FEP}=$ cefepime; $\mathrm{CAZ}=$ ceftazidime; $\mathrm{LEVOF}=$ levofloxacin; $\mathrm{AMI}=$ amikacin; $\mathrm{AMOXY}=$ amoxicillin; $\mathrm{IMI}=\mathrm{Imipenem}$; $\mathrm{TOB}=$ tobramycin; $\quad \mathrm{CTX}=$ cefotaxim; $\mathrm{NORFX}=$ norfloxacin; $\mathrm{SAM}=$ ampicillin+sulbactam; $\mathrm{MRP}=$ meropenem; $\mathrm{GEN}=$ gentamicin; $\mathrm{PI}+\mathrm{IZ}=$ piperacillin+Tazobactum; $\mathrm{AMC}=$ amoxicillin+clavulonate

\section{RESULTS AND DISCUSSION}

\section{Resistance of Acinetobacter sp to antibiotics}

As the tab 1 is shown, the resistant profile of 35 clinical isolates were included: CIPR (65.7\%), CTX (60\%), CAZ (74.2\%), LEVOF (48.6\%), AMI (42.9\%), AMOXY (97.1\%), IMI (65.7\%), TOB (25.7\%), CTX (91.4\%), NORFX (74.3\%), SAM (60\%), MRP (74.3\%), GEN (71.4\%), PI+IZ (62.8\%), AMC (74.2\%). The higher sensitivity was for TOB and AMI (tab 1).

\section{Chemical composition and antibacterial screening}

The antibacterial evaluation of essential oils against clinical isolates of Acinetobacter sp. by disc diffusion method showed that the activity was increased dose dependently. Increasing in the amount of essential oils increased the inhibition zone diameter of essential oils (tab 3). The higher inhibition zone diameters were for $2 \mu \mathrm{l}$ of $C$. macropodum $(15.3 \pm 0.48 \mathrm{~mm})$, and $H$. persicum $(13.3 \pm 0.48 \mathrm{~mm})$.

The main components of $H$. persicum was n-octyl acetate $(72.3 \%), 2$-methyloctyl ester butanoic acid (5.5\%), 1-octanol (4.2\%) while the chemical composition of C. macropodum showed the presence of trans-ocimene (49.2\%), cis-ocimene $(23.6 \%), \gamma$-terpinene $(7.7 \%), \beta$-myrcene $(4.4 \%)$, p-cymene $(5.5 \%)$, and fenchyl acetate $(2.7 \%)$ as the main components (tab 2).
Table 2 Chemical attributes of essential oils

\begin{tabular}{|c|c|}
\hline Essential oil & Main components \\
\hline Cymbopogon olivieri & $\begin{array}{l}\text { Piperitone }(72.8 \%), 4 \text {-carene }(11.8 \%), \beta- \\
\text { himachalene }(7.6 \%)\end{array}$ \\
\hline Heracleum persicum & $\begin{array}{l}\text { n-octyl acetate }(72.3 \%), 2 \text {-methyl-octyl ester } \\
\text { butanoic acid }(5.5 \%), 1 \text {-octanol }(4.2 \%)\end{array}$ \\
\hline Juniperus comminus & $\begin{array}{l}\text { Camphene }(37.7 \%), \beta \text {-pinene }(15.7 \%), \gamma \text {-terpinene } \\
(12 \%), \text { murola- } 4(14), 5 \text {-diene (trans) }(11.8 \%), \alpha \text { - } \\
\text { terpinene }(1.89 \%)\end{array}$ \\
\hline Azillia eryngioides & $\begin{array}{l}\alpha \text {-pinene }(63.8 \%) \text {, bornyl acetate }(18.9 \%), \beta \text {-pinene } \\
(2.6 \%) \text {, linalool }(2.1 \%) \text {, z-citral }(1.3 \%)\end{array}$ \\
\hline Dacus carrota & $\begin{array}{l}\text { Carotol }(46.1 \%), 3 \text {-octen-5-yne, } 2,7 \text {-dimethyl-(z) } \\
(15.7 \%), \alpha \text {-pinene }(10.7 \%), \text { trans caryophyllene } \\
(4.6 \%), \text { trans- } \beta \text {-farnesene }(4.5 \%), \alpha \text {-bergamotene } \\
(2.53 \%)\end{array}$ \\
\hline Ferula gummosa & $\begin{array}{l}\beta \text {-pinene }(62.7 \%), \alpha \text {-pinene }(9.5 \%), \delta \text {-carene } \\
(7.5 \%)\end{array}$ \\
\hline Acorus calamus & $\begin{array}{l}\text { Cis-asarone }(27.5 \%) \text {, acorenone }(17.4 \%) \text {, elemene } \\
(8.9 \%), \alpha \text {-salinene }(7.2 \%) \text {, camphor }(3.1 \%), \\
\text { camphene }(2.6 \%)\end{array}$ \\
\hline Mentha pulegium & $\begin{array}{l}\text { Piperitone }(38.1 \%) \text {, piperitenone }(33.1 \%), \alpha- \\
\text { terpineol }(4.8 \%), 1,8 \text {-cineole }(4.1 \%), \text { piperitenone } \\
\text { oxide }(3.4 \%), \text { menthone }(3.0 \%)\end{array}$ \\
\hline Achillea biebersteinii & $\begin{array}{l}\text { Germacrene-D }(46.6 \%) \text {, camphor }(6.2 \%), 1,8- \\
\text { cineole }(5.2 \%) \text {, bicyclogemacrene }(4.8 \%) \text {, } \\
\text { spathulenol }(3.8 \%)\end{array}$ \\
\hline $\begin{array}{l}\text { Chaerophyllum } \\
\text { macropodum }\end{array}$ & $\begin{array}{l}\text { trans-ocimene }(49.2 \%) \text {, cis-ocimene }(23.6 \%), \gamma \text { - } \\
\text { terpinene }(7.7 \%), \beta \text {-myrcene }(4.4 \%), \text { p-cymene } \\
(5.8 \%) \text {, and fenchyl acetate }(2.7 \%)\end{array}$ \\
\hline
\end{tabular}

As we mentioned before, the higher sensitivity of antibiotics against clinical isolates of Acinetobacter sp. was for tobramycin, AMI and levofloxacin. The inhibition zone diameter of these antibiotics was $14.1,10.5$ and $12.5 \mathrm{~mm}$ respectively and was lower than $C$. macropodum essential oil. The MIC and MBC evaluation of these essential oils showed the different results with disc diffusion method.

The lower MIC and MBC values were for $C$. olivieri essential oil (1.4 and 1.9 $\mu \mathrm{l} / \mathrm{ml}$ ) and $J$. comminus $(1.9$ and $2.6 \mu \mathrm{l} / \mathrm{ml})$ followed by $C$. macropodum $(2.01$ and $3.2 \mu \mathrm{l} / \mathrm{ml})$, D. carrota $(2.1$ and $3.8 \mu \mathrm{l} / \mathrm{ml})$, A. eryngioides $(2.3$ and $3.1 \mu \mathrm{l} / \mathrm{ml})$ and $F$. gummosa $(2.4$ and $4 \mu \mathrm{l} / \mathrm{ml})$ essential oils. Piperitone $(72.8 \%)$, 4-carene $(11.8 \%), \beta$-himachalene $(7.6 \%)$ were found in $C$. olivieri essential oil. Camphene $(37.7 \%), \beta$-pinene $(15.7 \%), \gamma$-terpinene (12\%), murola-4(14), 5-diene (trans) $(11.8 \%), \alpha$-terpinene $(1.89 \%)$ were the main components of J. comminus essential oil. The MIC values for $H$. persicum $(3.5 \mu 1 / \mathrm{ml})$, A. biebersteinii $(3.6$ $\mu \mathrm{l} / \mathrm{ml})$, A. calamus $(3.9 \mu \mathrm{l} / \mathrm{ml})$ essential oils were almost the same but the MBC values were $4.8,5.7$ and $6.5 \mu 1 / \mathrm{ml}$, respectively. Therefore, there is no correlation between the inhibition zone diameter and MIC values $(\mathrm{P}>0.05)$

The inhibition zone diameters of these antibiotics were $14.1,10.5$ and $12.5 \mathrm{~mm}$ respectively and was lower than $C$. macropodum essential oil. The MIC and MBC evaluation of these essential oils showed the different results with disc diffusion method. The lower MIC and MBC values were for $C$. olivieri essential oil $(1.4$ and $1.9 \mu \mathrm{l} / \mathrm{ml})$ and $J$. comminus $(1.9$ and $2.6 \mu \mathrm{l} / \mathrm{ml})$ followed by $C$. macropodum $(2.01$ and $3.2 \mu \mathrm{l} / \mathrm{ml})$, D. carrota $(2.1$ and $3.8 \mu 1 / \mathrm{ml})$, A. eryngioides $(2.3$ and $3.1 \mu \mathrm{l} / \mathrm{ml})$ and $F$. gummosa $(2.4$ and $4 \mu \mathrm{l} / \mathrm{ml})$ essential oils.

Piperitone $(72.8 \%)$, 4-carene $(11.8 \%), \beta$-himachalene $(7.6 \%)$ were found in $C$. olivieri essential oil. Camphene (37.7\%), $\beta$-pinene $(15.7 \%), \gamma$-terpinene $(12 \%)$, murola-4(14),5-diene (trans) $(11.8 \%)$, $\alpha$-terpinene $(1.89 \%)$ were the main components of $J$. comminus essential oil. The MIC values for $H$. persicum $(3.5$ $\mu \mathrm{l} / \mathrm{ml})$, A. biebersteinii $(3.6 \mu \mathrm{l} / \mathrm{ml})$, A. calamus $(3.9 \mu 1 / \mathrm{ml})$ essential oils were almost the same but the MBC values were $4.8,5.7$ and $6.5 \mu \mathrm{l} / \mathrm{ml}$, respectively. Therefore, there is no correlation between the inhibition zone diameter and MIC values $(\mathrm{P}>0.05)$ 
Table 3 The antimicrobial activity of essential oils against clinical isolates of Acinetobacter sp.

\begin{tabular}{|c|c|c|c|c|c|c|}
\hline \multirow[t]{2}{*}{ Essential oil } & \multicolumn{4}{|c|}{ Inhibition Zone (Means \pm SE mm) } & \multicolumn{2}{|c|}{$\begin{array}{c}\text { Microbial Concentrate } \\
(\mu \mathrm{l} / \mathrm{ml})\end{array}$} \\
\hline & $0.5 \mu 1$ & $1 \mu \mathrm{l}$ & $2 \mu \mathrm{l}$ & $\mu \mathrm{g}$ & $\mathrm{MIC}$ & $\mathrm{MBC}$ \\
\hline C. olivieri & $6.2 \pm 0.1$ & $8.7 \pm 0.23$ & $11.9 \pm 0.21$ & - & $1.4 \pm 0.07$ & $1.9 \pm 0.11$ \\
\hline H. persicum & $6.2 \pm 0.07$ & $8.2 \pm 0.22$ & $13.3 \pm 0.48$ & - & $3.5 \pm 0.07$ & $4.8 \pm 0.15$ \\
\hline J. comminus & $6.3 \pm 0.09$ & $8.2 \pm 0.19$ & $11.5 \pm 0.17$ & - & $1.9 \pm 0.1$ & $2.6 \pm 0.14$ \\
\hline A. eryngioides & $6.1 \pm 0.03$ & $7.3 \pm 0.16$ & $10.2 \pm 0.24$ & - & $2.3 \pm 0.1$ & $3.1 \pm 0.14$ \\
\hline D. carrota & $6.1 \pm 0.03$ & $6.8 \pm 0.15$ & $10.6 \pm 0.24$ & - & $2.1 \pm 0.1$ & $3.8 \pm 0.19$ \\
\hline F. gummosa & $6.1 \pm 0.03$ & $6.5 \pm 0.74$ & $10.7 \pm 0.19$ & - & $2.4 \pm 0.09$ & $4 \pm 0.25$ \\
\hline A. calamus & $6.1 \pm 0.04$ & $7.7 \pm 0.17$ & $11.2 \pm 0.19$ & - & $3.9 \pm 0.11$ & $6.5 \pm 0.25$ \\
\hline M. pulegium & $6.7 \pm 0.12$ & $9.1 \pm 0.34$ & $13.6 \pm 0.25$ & - & $2.3 \pm 0.09$ & $4.1 \pm 0.24$ \\
\hline A. biebersteinii & $6.1 \pm 0.04$ & $7.7 \pm 0.16$ & $11.4 \pm 0.19$ & - & $3.6 \pm 0.11$ & $5.7 \pm 0.25$ \\
\hline C. macropodum & $8.4 \pm 0.3$ & $10.8 \pm 0.36$ & $15.3 \pm 0.48$ & - & $2.01 \pm 0.15$ & $3.2 \pm 0.35$ \\
\hline TOB & - & - & - & $14.1 \pm 1.1$ & & \\
\hline AMI & - & - & - & $10.5 \pm 1.2$ & & \\
\hline LEVOF & - & - & - & $12.5 \pm 1.2$ & & \\
\hline
\end{tabular}

Todays, interest in essential oils or extracts as alternative treatment due to their loss or no adverse effects and multifunctional properties such as antiinflammatory, analgesic, immune enhancing and antimicrobial activities are increasing. There are many investigations that evaluate the antibacterial activities of plant derivatives against Acinetobacter sp. as a main human pathological agent. The antibacterial activity of Foeniculum vulgare Miller essential oil (Jazani et al., 2009), garlic chloroform extract and allicin (Jazani et al., 2007), green tea aqueous extract (Hosseini Jazani et al., 2007), thyme essential oi (Lysakowska et al., 2011), Cassia fistula extract (Aneja et al., 2011), Satureja hortensis essential oil (Mihajilov-Krstev et al., 2009) were confirmed.

Table 4 Fractional Inhibitory Concentration (FIC) and FIC indices (FICI)

\begin{tabular}{lcc}
\hline & FIC & FICI \\
\hline Cymbopogon olivieri & 0.5 & 0.503 \\
AMI & 0.003 & \\
Heracleum persicum & 0.5 & 0.506 \\
AMI & 0.006 & \\
Juniperus comminus & 0.25 & 0.253 \\
AMI & 0.003 & \\
Azillia eryngioides & 0.015 & 0.065 \\
AMI & 0.05 & \\
Dacus carrota & 0.0004 & 0.0504 \\
AMI & 0.05 & \\
Ferula gummosa & 0.25 & 0.45 \\
AMI & 0.2 & \\
Acorus calamus & 0.5 & 0.503 \\
AMI & 0.003 & \\
Mentha pulegium & 0.003 & 0.503 \\
AMI & 0.5 & \\
Achillea biebersteinii & 0.004 & 0.204 \\
AMI & 0.2 & \\
Chaerophyllum macropodum & 0.0004 & 0.2004 \\
AMI & 0.2 & \\
\hline AMI amikacin; FIC of essental
\end{tabular}

AMI= amikacin; FIC of essential oil=MIC in combination with AMI; FIC of AMI = MIC in combination with essential oil, MIC of essential oil alone, MIC of AMI alone, FICI= FIC of essential oil+ FIC of AMI

This study evaluates the antibacterial activity of new essential oils against clinical isolates Acinetobacter sp. Other studies showed the chemical composition of essential oils play an essential role in their antimicrobial activity. It is shown, different chemotypes of basil essential oil including estragol, linalool-estragol, methyl eugenol-anethol, anethol chemotypes had different antibacterial activity against Acinetobacter sp. and exhibited more sensitivity to methyl eugenol chemotype than lonalool or estragol chemotypes (Koba et al., 2009).

Therefore, the different antibacterial activity of essential oils is related to the composition of essential oils. Among the 11 different essential oils, C. olivieri, J. comminus and $C$. macropodum showed the best antibacterial activity agains clinical isolates of Acinetobacter sp. Piperitone as the first main component of $C$. olivieri showed antimicrobial activity (Cardenas-Ortega et al., 2005, Shahverdi et al., 2004). Camphene (Gerige and Ramjaneyulu, 2007), $\beta$-pinene(Andrew et al., 1980), $\gamma$-terpinene (Cristani et al., 2007) is responsible for antibacteria activityof J. comminus essential oil.

\section{Synergistic evaluation}

The synergistic evaluation of essential oils and AMI showed synergistic effect (the FICI was lower than 0.5). D. carrota and A. eryngioides showed the best synergistic effect with AMI, followed by C. macropodum, A. biebersteinii,J. comminus and Ferula gummosa essential oils (tab 4). The results of synergistic evaluation showed that all of the essential oils decreased the MIC value of AMI.
The lower FICIs were for D. carrota and A. eryngioides essential oils. Therefore, it does not mean that the essential oil with higher antibacterial activity has the higher synergistic effect. It is showed that piperitone has increased the antimicrobial activity of Furazolidone and nitrofurantoin (Shahverdi et al. 2004)

Furtheremore, the synergistic effects of AMI with lemon essential oil (Guerra $\boldsymbol{e}$ al., 2011), ciprofloxacin, gentamycin, piperacillin, tetracycline, cefoprazone with Coriandrum sativum essential oil (Duarte et al., 2012) were reported. Therefore, C. olivieri, J. comminus and C. macropodum essential oils can be used as alternative treatment for controlling of Acinetobacter sp. Therefore, D. carrota and $A$. eryngioides can be used along with AMI for decreasing the effective dose of this antibiotics. More clinical studies are used for exhibiting the efficacies in clinical trials.

\section{CONCLUSION}

This study evaluate the antibacterial activity of ten essential oils against clinical isolates of Acinetobacter sp. The results of antibacterial screening showed different essential oils with different chemical composition has different antibacterial activity. Among ten essential oils, $C$. macropodum, C. olivieri and $J$. comminus $(1.9$ and $2.6 \mu \mathrm{l} / \mathrm{ml})$ has the higher antibacterial activity agains Acinetobacter sp. AMI showed synergistic effect with all of the essential oils. $D$. carrota and A. eryngioides showed the best synergistic effect with AMI, followed by C. macropodum, A. biebersteinii,J. comminus and F. gummosa essential oils. Therefore, these essential oils can be as alternative treatment for lowering dose of AMI. More clinical studies are required to providing these essential oils in clinical.

Acknowledgments: This study is supported by Barij Essence Pharmaceutical Co. The authors are thankful to Mrs. Laleh Hejazi and Dr. Mohsen Taghizadeh

\section{REFERENCES}

ADAMS, R.P. 2001. Identification of Essential oil Components by Gas Chromatography/ Mass Spectroscopy, Allured Publishing Corp., Carol Stream, IL.

ANDREW, R.E., PARKS, L.W., SPENCE, K.D. 1980. Some effects of Douglas fir terpenes on certain microorganisms. Appliedand EnvironmentalMicrobiology, 40,301-304.

ANEJA, K.R., SHARMA, C., JOSHI, R. 2011. In vitro efficacy of amaltas (Cassia fistula L.) against the pathogens causing Otitis externa. Jundishapur Journal of Microbiology, 4(3), 175-183.

CANDAN, F., UNLU, M., TEPE, B., DAFERERA, D., POLISSIOU, M., SOKMEN, A., AKPULAT, H.A. 2003. Antioxidant and antimicrobial activity of the essential oil and methanol extracts of Achillea millefolium subsp. millefolium Afan. (Asteraceae). Journal of Ethnopharmacology, 87, 215-220. http://dx.doi.org/10.1016/S0378-8741(03)00149-1

CARDENAS-ORTEGA, N.C., ZAVALA-SANCHES, M.A., AGUIRRERIVERA, J.R., PEREZ-GONZALEZ, C., PEREZ-GUTIERREZ, S. 2005 Chemical composition and antifungal activity of essential oil of Chrysactinia mexicana Gray. Journal of Agricultural Food and Chemistry, 3, 4347 4349.http://pubs.acs.org/doi/abs/10.1021/jf040372h

CRISTANI, M., ARRIGO, M.D., MANDALARI, G., CASTELLI, F., SARPIETRO, M.G., MICIELI, D, VENUTI, V., BISIGNANO, G., SAIJA, A. TROMBETTA, D. 2007. Interaction of four monoterpenes contained in essential oils with model membranes: Implications for their antibacterial activity. Journal of Agricultural Food and Chemistry,55,6300-6308 http://pubs.acs.org/doi/abs/10.1021/jf070094x

DAMJANOVIC-VRATNICA, B., ĐAKOV, T., ŠUKOVIC, D., DAMJANOVIC J. 2011. Antimicrobial Effect of Essential Oil Isolated from Eucalyptus 
globulusLabill. from Montenegro. Czech Journal of Food Science 29(3), 277 284.

DUARTE, A., FERREIRA, S., SILVA, F., DOMINGUES, F.C. 2012 Synergistic activity of coriander oil and conventional antibiotics against Acinetobacter baumannii. Phytomedicine, 19,236-238. http://dx.doi.org/10.1016/j.phymed.2011.11.010

GERIGE, S.J., RAMJANEYULU, U. 2007. Antimicrobial activity of Melia dubia leaf volatile oil and camphene compound against skin pathogens. International Journal of Plant Science, 2(2), 166-168.

GUERRA, F.Q., MENDES, J.M., SOUSA, J.P., MORAIS-BRAGA, M.F., SANTOS, B.H., MELO COUTINHO, H.D., LIMA, E.D. 2011. Increasing antibiotic activity against a multidrug-resistant Acinetobacter spp by essential oils of Citrus limon and Cinnamomum zeylanicum. Natural Product Research 26(23),1-4. http://dx.doi.org/10.1080/14786419.2011.647019

HOSSEINI JAZANI, N., SHAHBI,S.H., ABDI, A.A., ZARTOSHTI, M. 2007.

Antibacterial effects of water soluble green tea extracts on Multi-antibiotic Resistant isolates of Acinetobacter sp. Pakistan Journal BiologicalSciences, 10(9),1477-1480. http://scialert.net/abstract/?doi=pjbs.2007.1477.1480

JAZANI, N.H., ZARTOSHTI, M., BABAZADEH, H., ALI-DAIEE, N., ZARRIN, S., HOSSEINI, S. 2009. Antibacterial effects of Iranian Fennel essential oil on isolates of Acinetobacter baumanii. Pakistan Journal BiologicalSciences,

http://scialert.net/abstract/?doi=pjbs.2009.738.741

12(9),738-741.

JAZANI, N.H., SHAHBI, S., ABDI ALI, A., ZARRIN, S., ALI-DAIEE, N. 2007. In vitro antibacterial activity of garlic against isolates of Acinetobacter $\mathrm{sp}$. $\begin{array}{lllll}\text { Journal of } & \text { Biological Science } & 7(5), & 819-\end{array}$ http://scialert.net/abstract/?doi=jbs.2007.819.822

KOBA, K., POUTOULI, P.W., RAYNAUD, C., CHAUMONT, J.P., SANDA, K. 2009. Chemical composition and antimicrobial properties of different basil essential oils chemotypes from Togo. Bangladesh J Pharmacol 4, 1-8. DOI: 10.3329/bjp.v4i1.998

ŁYSAKOWSKA, M., DENYS, A., SIENKIEWICZ, M. 2011. The activity of thyme essential oil against Acinetobacter spp. Central European Journal of Biology, 6(3), 405-413.

MIKAILI, P., JAZANI, N.H., SHAYEGH, J., HAGHIGHI, N. AGHAMOHAMMADI, N., ZARTOSHTI, M. 2011. The aerial parts of Stachys schtschegleevii Son. as hydroalcoholic extract has antibacterial activity on multidrug resistant bacterial isolates in comparison to ciprofloxacin. Journal of American Science, 7(8), 694-699.

MIHAJILOV-KRESTEV, T., RADNOVIC, D., KITIC, D., ZLATKOVIC, B RISTIC, M., BRANKOVIC, S. 2009. Chemical composition and antimicrobial activity of Satureja hortensis L. essential oil. Central European Journal of Biology,4(3):411-416. http://dx.doi.org/10.2478/s11535-009-0027-z

NCCLS. 2009. Methods For dilution Antimicrobial susceptibility tests for bacteria that grow aerobically. Approved Standard M7-A8, Eighth Edition, and Wayne, Pennsylvania.

NCCLS. 2012. Performance Standards for Antimicrobial Disc Susceptibility Test. Tentative standard, M02-A11 Vol. 32. Eleventh Edition, Wayne, Pennsylvania.

ROSATO, A., VITALI, C., DE LAURENTIS, N., ARMENISE, D., MILILLO, M.A. 2007. Antibacterial effect of some essential oils administered alone or in combination with Norfloxacin. Phytomed 14,727-732. http://dx.doi.org/10.1016/j.phymed.2007.01.005

SHAHVERDI, A.R., RAFII, F., FAZELI, M.R., JAMALIFAR, H., 2004. Enhancement of antimicrobial activity of furazolidone and nitrofurantoin against clinical isolates of Enterobacteriaceae by piperitone. International Journal of Aromatherapy 14, 77-80.http://dx.doi.org/10.1016/j.bbr.2011.03.031

SIENKIEWICZ, M., DENYS, P., KOWALCZYK, E. 2011. Antibacterial and immunostimulatory effect of essential oils. International Review of Allergology and Clinical Immunology,17(1-2), 40-

44.http://dx.doi.org/10.1016/j.ijat.2004.04.007.

TALBOT, G. H., BRADLEY, J., EDWARDS, J. E., GILBERT, Jr. D., SCHELD, M., BARTLETT, J.G. 2006. Bad bugs need drugs: an update on the development pipeline from the Antimicrobial Availability Task Force of the Infectious Diseases Society of America. Clinical Infectious Diseases, 42,657668. http://dx.doi.org/10.1086/499819

VAN LOOVEREN, M., GOOSSENS, H. 2004. Antimicrobial resistance of Acinetobacter spp. in Europe. Clinical Microbiology and Infection 10,684-704. http://onlinelibrary.wiley.com/doi/10.1111/j.1469-0691.2004.01035.x/full 